\title{
Tomasz Jarmużek, On the Sea-Battle Tomorrow That May Not Happen. A Logical and Philosophical Analysis of the Master Argument (Berno: Peter Lang, 2019), ss. 262
}

DOI: http://dx.doi.org/10.12775/RF.2021.031

Myśliciele od wieków zadają sobie pytania o to, czy przyszłość określona jest według przesądzonego wzoru, a losem człowieka kieruje nieuchronne fatum. Rozważania te przyczyniły się do rozwoju antycznej filozofii, twórczości oraz logiki, a Arystotelesowskie pytanie - Czy jutro będzie bitwa morska? - stało się ikoną problemu wartości logicznej zdań o przyszłości.

Monografia On the Sea-Battle Tomorrow That May Not Happen podejmuje antyczny problem sporu o determinizm w kontekście jutrzejszej bitwy morskiej Arystotelesa. W książce nakreślona zostaje problematyka relacji pomiędzy pojęciami czasu, wartości logicznej zdań i determinizmu na tle historycznego sporu Arystotelesa z Diodorem Kronosem. W dalszej części autor rekonstruuje i analizuje Rozumowanie Mistrza przy użyciu współczesnych narzędzi logicznych. Swą nazwę Mistrzowskie Rozumowanie zawdzięcza posiadanej przez Diodora mocy przekonywania. Niestety, rozumowanie to znane jest tylko ze źródeł wtórnych, ponieważ, w przeciwieństwie do pism Arystotelesa, nie zachowało się żadne oryginalne pismo Diodora. Jest to przyczyną niejasności co do konsekwencji pojmowania przez niego problemu możliwości. Zdarza się zatem, że podejściu Diodora zarzuca się narzucenie zdarzeniom przyszłym takiej samej konieczności, co zdarzeniom, które już się wydarzyły ${ }^{1}$. Czas jest tu liniowy, zobrazowany jedną prosta, niemającą żadnych rozgałęzień, co wyklucza możliwość wolności wyboru przyszłych zdarzeń, gdyż są one z góry przesądzone ${ }^{2}$. Autor pozycji On the Sea-Battle Tomorrow That May

1 Laura Lilianna Gomez Espíndola, „Disputas de Aristóteles y Diodoro Crono en torno a la necesidad lógica", Praxis Filosófica 35 (2012): 39-57; Tomasz Jarmużek, „Master Argument vs. Sea-Fight Tomorrow”, Bulletin of the Section of Logic 38, 3-4 (2009): 205-214.

2 Amalia Quevedo, „Posibilidad e Indeterminación. Aristóteles Frente a Dio- 
Not Happen, posługując się narzędziami logiczno-formalnymi, przekonuje jednak, że rozumowanie Diodora Kronosa nie wymusza linearnej struktury czasu, a co za tym idzie - determinizmu.

Arystoteles pisał, że wartość logiczna zdań dotyczących przyszłości jest przygodna. Jednak $w$ aspekcie antycznego sporu o determinizm Stagirycie zarzuca się niekiedy, że „w rzeczy samej Arystoteles zajmuje się argumentacją [tego zagadnienia] głównie w aspekcie metafizycznym (i fizycznym), nie zaś logicznym"3 ${ }^{3}$. Definicja możliwości Diodora głosiła natomiast, że „możliwe jest to, co jest, lub to, co będzie” w przyszłości. Jak pisze Amalia Quevedo, tym, co zdaje się sugerować determinizm w podejściu Diodora, jest to, że interpretacja jego definicji możliwości nie pozostawia alternatywy dla przyszłych wydarzeń, nie jest w niej bowiem możliwe nic innego poza tym, co już jest i co będzie. W monografii natomiast pokazano, że rekonstrukcja argumentacji Diodora nie wyklucza zastosowania logik, które dopuszczają rozgałęzianie się struktury czasu. Dowodzi to, że Rozumowanie Mistrza nie narzuca wcale determinizmu.

Omawiana publikacja jest podzielona na trzy części. Pierwsza, Filozoficzne ramy problematyki, stanowi wprowadzenie do analizowanego zagadnienia, będąc przy tym ramą pojęciową dalszych rozważań. Zostają w niej przedstawione kwestie związku pomiędzy zdaniami a ich wartością logiczną jak również podkreślony ich kontekst czasowy. Autor, nakreślając problem wielowymiarowości pojęcia czasu ${ }^{4}$, objaśnia terminy „determinizm” oraz „czas", dążąc do podania takich pojęć, które będą stanowiły bazę dalszych rozważań. Zostają zatem określone takie warunki przedmiotowe, w których dowolne zdania mają wartość logiczna, oraz opisane ogólne pojęcie struktury czasu.

Autor opisuje historyczny spór o determinizm, tym samym rozpoczynając kolejną część publikacji - Problematykę. Zawiera ona historyczny oraz filozoficzny kontekst problemu jutrzejszej bitwy morskiej, a także Mistrzowskiego Rozumowania. Tomasz Jarmużek objaśnia definicję zdania możliwego Diodora oraz przesłanki służące do jej wyprowadzenia. Przedstawia również narzędzia logiczne niezbędne do przeprowadzenia rekonstrukcji rozumowania, które wykraczają poza pojęcia i narzędzia logiczne dostępne w starożytności. W ten sposób w monografii wykorzystane zostają

doro Crono", Thémata 6 (1989): 129; Roy Weatherford, The Implications of Determinism, Vol. 8 (Taylor \& Francis: 2017).

3 Dario Ettari, „La polemica sul possibile nel IV secolo aC [Aristotele, Filone, Diodoro Crono, Crisippo] in una interpretazione moderna", Metalogicon XV, 1 (2002): 28.

4 Tomasz Jarmużek, „Różne oblicza czasu i ich wspólny fundament”, Przegląd Filozoficzny - Nowa Seria 55, 3 (2005): 47-55. 
logiki temporalne, mające swój początek w pierwszej połowie XX wieku. Formalizują one wnioskowania, w których istotną rolę odgrywają pojęcia czasowe. Struktura czasu zostaje natomiast zdefiniowana przez autora jako para $\langle\mathrm{T}, \leq\rangle$ (gdzie $\mathrm{T}$ jest zbiorem momentów, a $\leq$ dwuczłonową relacją wcześniej-później) (s. 181, def. 7.2.11).

Trzecia i zarazem ostatnia część monografii to Rozwiązania. Autor prezentuje i dyskutuje w niej różne próby rekonstrukcji Rozumowania Mistrza. Są one podzielone na dwie kategorie. Pierwsza z nich zawiera rekonstrukcje oparte na zastosowaniu logiki pozycyjnej - po przytoczeniu rekonstrukcji F. S. Michaela i N. Reschera zaprezentowana zostaje rekonstrukcja autorska. W kategorii niewymagającej użycia logiki pozycyjnej omówione zostają rekonstrukcje A. N. Priora ${ }^{5}$ oraz P. Øhrstrøma. Niektóre $\mathrm{z}$ rekonstrukcji, dopuszczając rozgałęzianie się czasu, stanowią argument na rzecz indeterminizmu w rozumowaniu Diodora.

Jakkolwiek zagadnienie Mistrzowskiego Rozumowania było już podejmowane przez wielu autorów ${ }^{6}$, omawiana monografia prezentuje je w świeży, nowatorski sposób, przy jednoczesnym rzetelnym uwzględnieniu istniejących źródeł. Argumentacja, zobrazowana wieloma przykładami, jest klarowna i dobrze zorganizowana. Natomiast cel, przedstawiony na wstępie, zostaje w pełni osiągnięty - po rekonstrukcji i analizie Rozumowania Mistrza staje się jasne, że wbrew panującym przekonaniom nie prowadzi ono w sposób konieczny do determinizmu.

Anna Rzeczkowska

Uniwersytet Mikołaja Kopernika, Toruń

ORCID: 0000-0003-2856-6105

e-mail: anna.rzeczkowska98@gmail.com

\section{Bibliografia}

Ettari Dario. 2002. „La polemica sul possibile nel IV secolo aC [Aristotele, Filone, Diodoro Crono, Crisippo] in una interpretazione moderna". Metalogicon XV, 1: 27-32.

5 Tomasz Jarmużek, Andrzej Pietruszczak, „The Tense Logic for Master Argument in Prior's Reconstruction", Studia Logica 92 (2009): 85-108.

6 Hermann Weidemann, "Aristotle, the Megarics, and Diodorus Cronus on the Notion of Possibility", American Philosophical Quarterly 45, 2 (2008): 131-148; Quevedo, „Posibilidad e Indeterminación”: 125-136; Gomez Espíndola, „Disputas de Aristóteles y Diodoro Crono en torno a la necesidad lógica": 39-57. 
Gomez Espíndola Laura Lilianna. 2012. „Disputas de Aristóteles y Diodoro Crono en torno a la necesidad lógica". Praxis Filosófica 35: 39-57.

Jarmużek Tomasz. 2005. „Różne oblicza czasu i ich wspólny fundament”. Przegląd Filozoficzny - Nowa Seria 55, 3: 47-55.

Jarmużek Tomasz. 2006. „Rekonstrukcje rozumowania Diodora Kronosa w ontologii czasu punktowego". Analiza i Egzystencja 3: 197-215.

Jarmużek Tomasz. 2009. „Master Argument vs. Sea-Fight Tomorrow”. Bulletin of the Section of Logic 38, 3-4: 205-214.

Jarmużek Tomasz. 2013. Jutrzejsza bitwa morska. Rozumowanie Diodora Kronosa. Toruń: Wydawnictwo Naukowe Uniwersytetu Mikołaja Kopernika.

Jarmużek Tomasz. 2019. On the Sea Battle Tomorrow That May Not Happen: A Logical and Philosophical Analysis of the Master Argument. Berno: Peter Lang GmbH, Internationaler Verlag der Wissenschaften.

Jarmużek Tomasz, Pietruszczak Andrzej. 2009. „The Tense Logic for Master Argument in Prior's Reconstruction”. Studia Logica 92: 85-108.

Quevedo Amalia. 1989. „Posibilidad e Indeterminación. Aristóteles Frente a Diodoro Crono". Thémata 6: 125-136.

Weatherford Roy. 2017. The Implications of Determinism, Vol. 8. Taylor \& Francis.

Weidemann Hermann. 2008. "Aristotle, the Megarics, and Diodorus Cronus on the Notion of Possibility". American Philosophical Quarterly 45, 2: 131-148. 